\title{
Native pipefish Entelurus aequoreus are promoted by the introduced seaweed Sargassum muticum in the northern Wadden Sea, North Sea
}

\author{
Patrick Polte $^{1,2, *}$, Christian Buschbaum ${ }^{1}$ \\ ${ }^{1}$ Alfred Wegener Institute for Polar and Marine Research, Wadden Sea Station Sylt, Hafenstr. 43, 25992 List, Germany \\ ${ }^{2}$ Present address: Northwest Fisheries Science Center, NOAA Fisheries, 2725 Montlake Blvd. East, Seattle, \\ Washington 98112-2097, USA
}

\begin{abstract}
After the major loss of eelgrass habitats in the 1930s the snake pipefish Entelurus aequoreus was considered to be rare in the Wadden Sea (south-eastern North Sea, German Bight). We hypothesize that a sudden increase in pipefish abundance observed in the area since 2004 is related to new habitats provided by the introduced Japanese seaweed Sargassum muticum. SCUBA observations conducted near the Island of Sylt during July 2006 showed that approximately every second $S$. muticum thallus was inhabited by E. aequoreus, whereas no pipefish could be found on sedimentary areas dominating the Wadden Sea. In a field experiment, we removed thalli from a $S$. muticum bed and transplanted them to an unvegetated site and to the donor $S$. muticum bed, respectively. Nine days after the transplantation, abundances of pipefish per thallus were almost equally high within all transplanted $S$. muticum units at vegetated and originally unvegetated sites. Abundances of $E$. aequoreus in transplanted thalli did not significantly differ from those found in unaffected control thalli located in the donor $S$. muticum bed. To explain high pipefish densities within $S$. muticum beds we sampled the zooplankton community inside and outside the $S$. muticum bed and compared it with gut contents of pipefish. Zooplankton densities were significantly higher inside the S. muticum bed. Harpacticoid copepods were the dominant group associated with S. muticum and also represented the major prey of E. aequoreus. We conclude that stocks of E. aequoreus are promoted by $S$. muticum beds since they benefit from higher food supply during the spawning season, probably in addition to increased shelter by habitat complexity. Results of the present study suggest that introductions of habitat-forming species such as $S$. muticum may cause beneficial effects on abundance and diversity of native species.
\end{abstract}

KEY WORDS: Introduced seaweed • Pipefish • Sargassum muticum • Entelurus aequoreus . Zooplankton · Wadden Sea $\cdot$ North Sea

Resale or republication not permitted without written consent of the publishe

\section{INTRODUCTION}

In coastal ecosystems biogenic habitats composed of macrophytes such as seagrasses are generally known to increase abundance and species diversity of associated fish communities (e.g. Pollard 1984, Jackson et al. 2001, Franco et al. 2006). In the Wadden Sea, shallowwater fish diversity is considered to have declined since the major loss of subtidal seagrass habitats during the 1930s (Wolff 2000, Polte 2004), when an infec- tion by a parasitic slime mould (Labyrinthula zosterae) caused a severe decline of subtidal Zostera marina stocks that have not recovered in the Wadden Sea area (den Hartog 1987, de Jonge et al. 2000). Species such as the broad-nose pipefish Syngnathus typhle, the sea stickleback Spinachia spinachia, and the snake pipefish Entelurus aequoreus (all: Linnaeus, 1758) attributed to the seagrass fish community (Wohlenberg 1935, Redeke 1941, Nijssen \& de Groot 1987) became rare in the area, most probably because of the lack of 
complex macrophyte habitats in the shallow subtidal zone (Berg et al. 1996). During fish surveys carried out in 2003 on intertidal seagrass beds (Zostera noltii), mussel beds (Mytilus edulis) and sand flats, as well as in subtidal areas where $Z$. marina formerly occurred and which were unvegetated at the time of sampling, none of the named fish species could be found (Polte 2004, Polte \& Asmus 2006). However, since 2004 S. spinachia and E. aequoreus could be observed more frequently in the northern Wadden Sea (P. Polte \& C. Buschbaum unpubl. data). Snake pipefish E. aequoreus in particular was found in exceptionally high abundances in the north-eastern Atlantic Ocean during the last 5 yr (Kirby et al. 2006, Lindley et al. 2006, Harris et al. 2007, 2008, Kloppmann \& Ulleweit 2007). The reason for the strong increase of the snake pipefish population has been attributed so far to global warming and a rise in sea surface temperatures that benefit reproduction and survival of larvae (Kirby et al. 2006, Lindley et al. 2006).

Based on observations in the northern Wadden Sea (south-eastern North Sea), we assume that the increasing success of the introduced Japanese seaweed Sargassum muticum (Yendo) might also represent a key factor promoting Entelurus aequoreus by providing important habitats, especially during the spawning season, when males that conduct parental care find shelter and an enriched food supply within the $S$. muticum beds.

Sargassum muticum is highly invasive and, currently, has an almost worldwide distribution. Probably as a result of oyster Crassostrea gigas Thunberg aquaculture activities, it became introduced to northern Europe in 1976. From the English Channel $S$. muticum rapidly spread north- and southward. Because of its successful reproductive strategy by self-fertilisation (Fletcher 1975, Norton 1976, 1977) and efficient dispersal mechanism by floating thalli, its current distribution reaches from Portugal to Scandinavia (Druehl 1973, Critchley 1983, Rueness 1989, Karlsson \& Loo 1999, Wolff 2005). After establishment, densities of $S$. muticum have strongly increased along European coasts (e.g. Critchley et al. 1987, Karlsson \& Loo 1999, Staehr et al. 2000).

Sargassum muticum became established in the southern range of the Wadden Sea in 1980, where it was first found at the Dutch island of Texel. Since 1993, S. muticum can regularly be found near the Island of Sylt (Germany) in the northern Wadden Sea (Kornmann \& Sahling 1994). In this area, S. muticum grows in the shallow subtidal zone at the particular tidal level where eelgrass Zostera marina occurred before stocks vanished. In the sedimentary environment of the Wadden Sea, S. muticum preferentially settles on epibenthic molluscs such as native blue mussels Mytilus edulis and the introduced Pacific oyster Crassostrea gigas (Buschbaum 2005, Buschbaum et al. 2006). In cold waters $S$. muticum is pseudo-perennial. The lateral branches detach in summer and early autumn, leaving a short perennial stipe from which thalli regenerate during the following spring (e.g. Jephson \& Gray 1977) and may achieve a length of $>4$ m during summer. Other habitat-forming algae are very rare in the subtidal zone of the Wadden Sea. Hence, S. muticum with its long and complex thalli might serve as a compensatory habitat to native fishes that have been associated with seagrass habitats provided that those fish species are still present on the North Sea scale. Thus, we hypothesised, that: (1) when $S$. muticum occurs in the shallow subtidal zone it will become inhabited by snake pipefish and (2) the density of planktonic prey is significantly higher within $S$. muticum beds compared to unvegetated areas.

\section{MATERIALS AND METHODS}

Study sites. Studies were conducted on the east coast of the Island of Sylt in the northern Wadden Sea (North Sea) (Fig. 1). A shallow tidal basin is formed by the mainland and the islands of Sylt (Germany) and Rømø (Denmark). Along the tidal watersheds the Sylt-Rømø Bight is nearly closed by causeways connecting the islands with the mainland. A single inlet opens the bight to the open North Sea. Tides are semi-diurnal, with an average amplitude of about $2 \mathrm{~m}$. Salinity ranges seasonally from 28 in winter to 32 in summer. During the vegetation period of Sargassum muticum from February to August, water temperatures vary seasonally from 1 to $20^{\circ} \mathrm{C}$. During the investigation period in July 2006, the mean water temperature was $18^{\circ} \mathrm{C}$. Mean water depth in the investigated areas ranged from $0.5 \mathrm{~m}$ (mean low tide line) to $2 \mathrm{~m}$ (mean high tide line).

The intertidal and shallow subtidal zone of the Sylt-Rømø Bight is dominated by bare sandy to muddy sediments. Today, seagrass beds are limited to the intertidal zone and dominated by the dwarf seagrass Zostera nolti, Hornemann, covering approximately $12 \%$ of tidal flats (Gätje \& Reise 1998). Mussel beds (Mytilus edulis) used to cover $0.3 \%$ of the intertidal zone (Gätje \& Reise 1998), but may show interannual variations. However, during the last $3 \mathrm{yr}$, they have become increasingly invaded by the Pacific oyster Crassostrea gigas (Diederich 2006), leading to a shift in landscape from mussel beds to oyster reefs. Introduced by oyster aquaculture, Sargassum muticum has spread in the shallow subtidal zone since 1993 in the range of mussel beds, oyster reefs and breakwaters (Kornmann \& Sahling 1994, Buschbaum 2005, Buschbaum et al. 2006). Studies were conducted in a $S$. muticum bed 

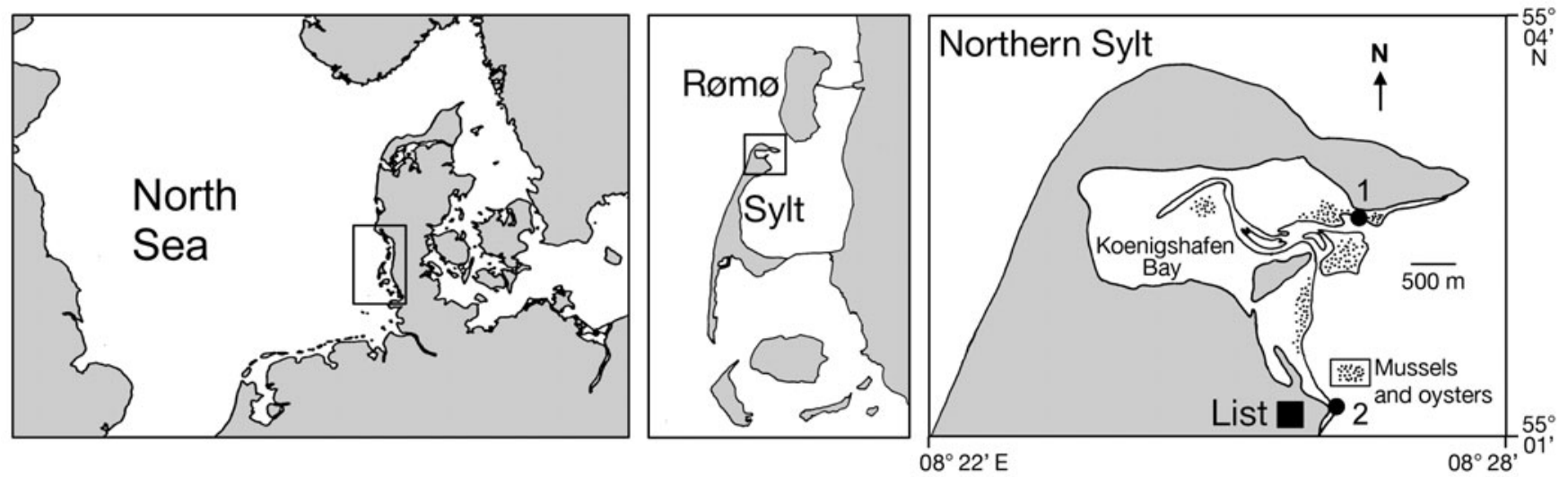

Fig. 1. Location of study area. Investigated Sargassum muticum bed (1) and List Breakwater (2).

Village of List

located in the subtidal zone on the northern side of Koenigshafen Bay (a shallow subsystem of the SyltRømø Bight) and on unvegetated soft sediments located about $3.5 \mathrm{~km}$ south, in the reach of a sheltering breakwater (List Breakwater), off the village of List (Fig. 1). This site was chosen because it fulfils the habitat requirements of $S$. muticum more closely than exposed sand flats and was, therefore, considered to bring the experimental setup as close to natural conditions as possible.

Density and biomass of Sargassum muticum. On 10 July 2006, abundance and biomass of Sargassum muticum thalli were measured in a seaweed bed that was used as a donor area for experimental transplantation of $S$. muticum to study pipefish settlement (Fig. 1C, Site 1). Densities of thalli were counted in $3 \times$ $3 \mathrm{~m}$ plots $(\mathrm{n}=20)$, randomly chosen and defined by tape measure. Thalli were collected randomly $(n=10)$. The algae were detached from their substrata (oysters Crassostrea gigas and mussels Mytilus edulis), placed in a bucket (of known weight) and weighed ( $\mathrm{g}$ fresh wt) using a spring balance. Additionally, the length of each thallus was recorded using a tape measure.

Sargassum muticum transplantation experiment. To test the hypothesis that Wadden Sea areas will become inhabited by snake pipefish when $S$. muticum is present, $S$. muticum thalli $(\mathrm{n}=20)$ were randomly removed from the $S$. muticum bed. Afterwards, thalli were detached from the substrata and fresh wt and length were recorded. The thalli were attached to metal poles using cable ties fixed at the thallus' holdfast. Each unit was equipped with a small number tag fixed to the pole; 10 of the thalli were transplanted a distance of $2 \mathrm{~km}$ to the originally unvegetated site at List Breakwater and to a tidal level the same as that at the donor $S$. muticum bed.

Ten thalli attached to metal poles were re-transplanted to the donor Sargassum muticum bed to estimate transplantation effects. As control units, another 10 thalli located within the donor $S$. muticum bed were randomly chosen and not handled, except that number tags were fixed on the alga's holdfast right at the oyster substrate.

On 19 July, 9 d after transplanting the thalli, the abundance of pipefish on transplanted and control units was examined by SCUBA during high tide. Additionally, on unvegetated sandy sediments at List Breakwater, 5 replicate $30 \mathrm{~m}$ transects were controlled for the occurrence of pipefish.

Due to the experimental setup, the abundance of pipefish could not be measured per area directly. Instead, abundance was measured as the number of fish per Sargassum muticum thallus. Since Entelurus aequoreus shows minimal escape behaviour, especially when hiding camouflaged beneath the algae, fish per transplanted thallus could reliably be counted in situ. Pipefish abundance per area could be calculated secondarily from fish abundance per thallus and density of thalli per area. Specimens of E. aequoreus found near transplanted and control thalli were examined for eggs externally adhered to the trunk of male fish.

Analyses of pipefish gut contents. Individuals of Entelurus aequoreus were randomly collected within the Sargassum muticum bed $(\mathrm{n}=8)$. They were taken to the laboratory where total length and fresh wt were measured. Stomach contents were removed, diluted in seawater and brought into a plankton counting chamber. Organisms found in each stomach were counted and identified to taxonomic order. Fragmented organisms were quantified by counting only the heads.

Prey densities in the field. To investigate whether Sargassum muticum beds may provide an increased food supply to pipefish during the spawning season, the density of prey fauna within the Koenigshafen Bay $S$. muticum bed was compared to that of adjacent unvegetated areas located at the same tidal level (distance: approximately $20 \mathrm{~m}$ ). During incoming tide a 
plankton net of $1.60 \mathrm{~m}$ length and a diameter of $50 \mathrm{~cm}$ (mesh size: $250 \mu \mathrm{m}$ ) was brought to the bottom by a SCUBA diver. The ring frame of the net was carefully moved underneath the bivalve substrate, and the net was pulled vertically over single, submerged $S$. muticum thalli ( $\mathrm{n}=6$ ) (almost as long as the height of the water column) from the bottom to the water surface (depth: $1.60 \mathrm{~m}$ ). At the surface, prior to removing the $S$. muticum thallus from the net, the thallus was washed 3 times to remove adherent fauna. Outside the S. muticum bed a similar technique was conducted on unvegetated sediment, whereby the net was moved from the bottom to the surface over the same distance as inside the algal bed ( $\mathrm{n}=6$ ). The sampled water volume inside and outside the $S$. muticum bed was $0.3 \mathrm{~m}^{3}$ (area of the net opening $=0.2 \mathrm{~m}^{2} \times$ sampling distance $=$ $1.6 \mathrm{~m})$. Organisms were washed out of the removable cylinder attached to the bottom of the plankton net and fixed in $10 \%$ formalin. Organisms from vegetated and unvegetated areas were identified to taxonomic order. Due to the sampling technique used, the term 'zooplankton' is used here, although a number of orders caught are usually found close to the sea floor and might also be referred to as hypoplankton or epibenthos.

Data analysis. Results of quantitative assessments are presented as arithmetic means with standard errors $( \pm \mathrm{SE})$. Statistical effects were tested for significance using a 1-way analyses of variance (ANOVA). Datasets were tested for homoscedasticity by Cochran's test and transformed using $\log (x+1)$ if necessary to fulfil the assumptions for ANOVA. Effects between single treatments of the Sargassum muticum transplantation experiment were analysed using post hoc Tukey's honestly significant differences (HSD) test. Statistical significance was assumed if the p-level was $<0.05$.

\section{RESULTS}

\section{Sargassum muticum density and biomass}

In the investigated Sargassum muticum bed, mean density $( \pm \mathrm{SE})$ of thalli was $7 \pm 0.05$ per $10 \mathrm{~m}^{2}$. Thalli had a mean length of $1.4 \pm 0.1 \mathrm{~m}$ and a mean fresh wt of $0.47 \pm 0.05 \mathrm{~kg}$. The thalli transplanted during the experiment showed no significant differences with respect to length and weight (thallus length: ANOVA $\mathrm{p}=0.3, \mathrm{df}=2, F=1.2$; thallus fresh wt: ANOVA $\mathrm{p}=0.5$, $\mathrm{df}=2, F=0.7$ ).

\section{Abundance of Entelurus aequoreus}

No individuals of Entelurus aequoreus could be found on the unvegetated transects at List Breakwater (Fig. 1).
In the Sargassum muticum bed at Koenigshafen Bay (Fig. 1), the abundance of E. aequoreus per thallus in unaffected control thalli was $0.6 \pm 0.2$ ind. thallus ${ }^{-1}$. With a given $S$. muticum density of 7 thalli per $10 \mathrm{~m}^{2}$ (see above), abundance of $E$. aequoreus corresponds to 4.2 ind. per $10 \mathrm{~m}^{2}$. At the unvegetated site at List Breakwater, mean abundance of pipefish in transplanted $S$. muticum thalli was $0.6 \pm 0.2$ thallus $^{-1}$. In the transplanted thalli located within the donor $S$. muticum bed $0.5 \pm 0.2$ ind. thallus ${ }^{-1}$ were found (Fig. 2). Pipefish abundances in the experimental treatments showed no significant differences overall (ANOVA, $\mathrm{p}=0.9$, $\mathrm{df}=2$, $F=0.05)$.

Of all pipefish found in transplanted and control Sargassum muticum thalli during the investigation period, $57 \%$ were males carrying eggs adhered to their trunk. Note: Beside Entelurus aequoreus, 2 specimens of the sea stickleback Spinachia spinachia were observed inhabiting the transplanted S. muticum thalli, whereas none of these fish were observed at the unvegetated control site.

\section{Composition of pipefish diet}

Specimens of Entelurus aequoreus sampled for analysis of gut contents had a mean body length of $28.8 \pm 0.9 \mathrm{~cm}$ and a mean fresh wt of $2.9 \pm 0.3 \mathrm{~g}$. Harpacticoid copepods represented by far the majority of prey organisms found in the guts of pipefish from the Sargassum muticum bed. Barnacle and fish larvae, as well as amphipods and mysidaceans, were also found, but in comparably lower percentages (Table 1). Numerical mean abundances of prey groups per fish gut $(\mathrm{n}=8$ ) were as follows-harpacticoid copepods:

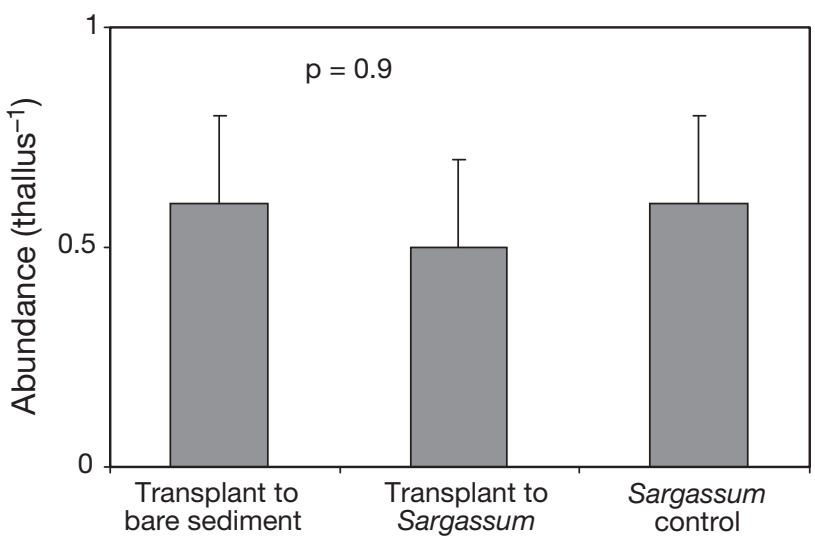

Fig. 2. Mean abundance $( \pm \mathrm{SE})$ of Entelurus aequoreus per Sargassum muticum thallus in the experimental transplantation and control units. All transplants were from the Sargassum donor bed (where the control was also located) in the Koenigshafen Bay area; the bare sediment site was at List breakwater 
Table 1. Mean percentages $( \pm \mathrm{SE})$ of prey organisms found in the guts of Entelurus aequoreus $(\mathrm{n}=8)$

\begin{tabular}{|lc|}
\hline Prey & Percent of prey per fish gut \\
\hline Harpacticoid copepods & $86.3 \pm 4.8$ \\
Cypris larvae & $4.5 \pm 1.5$ \\
Fish larvae & $5.5 \pm 3.7$ \\
Amphipods & $1.7 \pm 1.0$ \\
Mysidaceans & $0.6 \pm 0.3$ \\
\hline
\end{tabular}

$74.8 \pm 20.9$, barnacle (cypris) larvae: $2.4 \pm 0.8$, fish larvae: $1.4 \pm 0.7$, amphipods: $1.1 \pm 0.5$ and mysidaceans: $0.5 \pm 0.2$.

\section{Density of zooplankton groups associated with Sargassum muticum}

The zooplankton sampled in vegetated and unvegetated areas was dominated by copepod and amphipod crustaceans, as well as by planktonic stages of benthic larvae (meroplankton) such as polychaetes, gastropods, bivalves and balanids (Table 2). With $40.8 \pm$ 3.9 ind. per $0.3 \mathrm{~m}^{3}$, the mean density of zooplankton in total was significantly lower in the unvegetated area adjacent to the Sargassum muticum bed $(p=0.001$, df $=1, F=21.2$ ) than inside the bed where the total density was $768 \pm 158.5$ ind. per $0.3 \mathrm{~m}^{3}$. This is also true for all taxonomic groups. Numbers of copepods, amphipods and benthos larvae were all significantly higher in the $S$. muticum bed compared to unvegetated areas (Fig. 3) (copepods: $\mathrm{p}=0.001$, df $=1, F=$ 22.0; amphipods: $\mathrm{p}<0.001, \mathrm{df}=1, F=12.02$; benthos larvae: $p=0.006$, $d f=1, F=98.7$ ). Cypris stages of barnacle larvae (Balanidae) were the only group that showed slightly lower abundances inside $S$. muticum

Table 2. Mean density $( \pm \mathrm{SE})$ of zooplankton organisms per $0.3 \mathrm{~m}^{3}$, associated with Sargassum muticum and unvegetated areas

\begin{tabular}{|lcc|}
\hline Taxon & $\begin{array}{c}\text { Mean density per } 0.3 \mathrm{~m}^{3} \\
\text { S. muticum } \\
\text { present }\end{array}$ & $\begin{array}{c}\text { S. muticum } \\
\text { absent }\end{array}$ \\
\hline $\begin{array}{l}\text { Holoplankton } \\
\text { Copepoda }\end{array}$ & & \\
$\quad$ Calanoid & $3.5 \pm 0.4$ & $17.3 \pm 2.8$ \\
$\quad$ Cyclopoid & $17.8 \pm 3.0$ & $1.17 \pm 0.5$ \\
$\quad$ Harpacticoid & $599.8 \pm 122.3$ & $15.8 \pm 3.6$ \\
Amphipoda & $128.2 \pm 31.8$ & $1.5 \pm 0.8$ \\
Meroplankton & & \\
Polychaeta & $4.0 \pm 1.15$ & $0.5 \pm 0.34$ \\
Gastropoda & $1.3 \pm 0.4$ & $0.2 \pm 0.2$ \\
Bivalvia & $12.7 \pm 3.6$ & $3.8 \pm 1.4$ \\
Cirripedia & & \\
$\quad$ Balanidae & $0.2 \pm 0.2$ & $0.5 \pm 0.2$ \\
\hline
\end{tabular}

Within S. muticum bed $\square$ Outside S. muticum bed
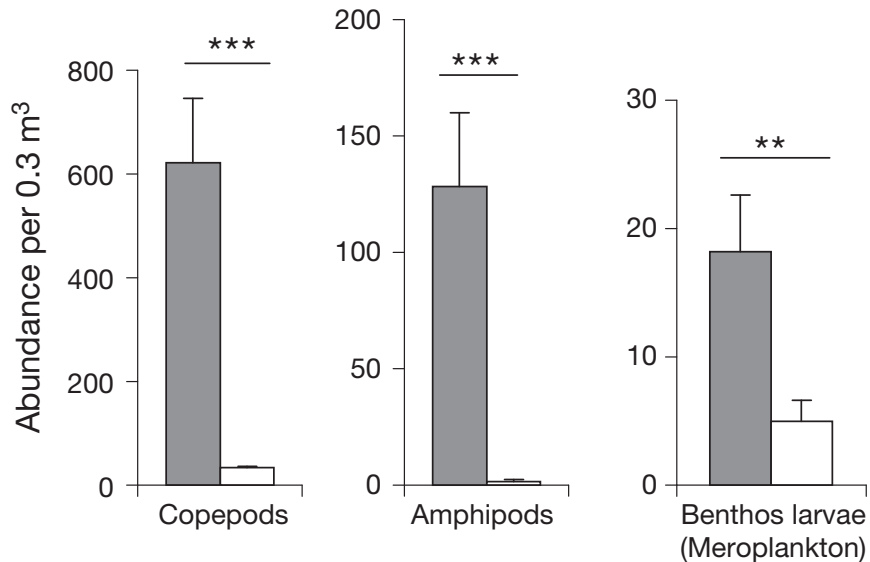

Fig. 3. Mean abundance $( \pm \mathrm{SE}, \mathrm{n}=6)$ of zooplankton per $0.3 \mathrm{~m}^{3}$ inside and outside the Sargassum muticum bed. ${ }^{* *} \mathrm{p} \leq 0.01 ;{ }^{* * *} \mathrm{p} \leq 0.001$

than on unvegetated areas. However, numbers of barnacle larvae found were very low, and differences were not significant $(\mathrm{p}=0.3, \mathrm{df}=1, F=1.4)$.

\section{DISCUSSION}

Results of the experimental transplantation of Sargassum muticum indicate that originally unvegetated areas where snake pipefish were absent became inhabited rapidly after Sargassum thalli were artificially introduced. In that area, abundance of Entelurus aequoreus reached the same level as in the donor $S$. muticum bed ( 1 fish per 2 thalli) within a little more than a week. The process of transplantation and the way thalli were artificially fixed at the site are not considered to have affected the results, since no difference in pipefish abundance could be observed among unaffected control thalli and re-transplants within the original $S$. muticum bed. Sex distribution of fish could not be assessed reliably in situ. In contrast to many syngnathid species in which males carry the eggs within a brood pouch, males of E. aequoreus carry the eggs externally adhered to their trunk (Vincent et al. 1995). Thus, egg-carrying males could easily be identified in situ. They made up $57 \%$ of total individuals found during the investigation period. This finding suggests that the vegetation period of $S$. muticum in the Wadden Sea from February to August coincides with the spawning season of E. aequoreus, which might point out a significant role of $S$. muticum habitats during pipefish reproduction, a sensitive phase in the fish's life cycle.

The density of planktonic prey, such as harpacticoid copepods, was significantly increased inside the Sar- 
gassum muticum bed compared to in adjacent unvegetated areas. The importance of harpacticoid copepods as a food source for pipefish is also described for other species of syngnathids (Tripton \& Bell 1988). However, prey composition varies among syngnatid species due to morphological differences such as snout length and species mobility (Kendrick \& Hyndes 2005). Since data on the diet of Entelurus aequoreus are limited to fish taken from the $S$. muticum bed, results are biased and are not suggested to cover the entire spectrum of potential prey. However, they demonstrate that the harpacticoid copepods that dominated the plankton community inside the $S$. muticum bed are a suitable food for pipefish and are extensively preyed on. Based on these results it can be concluded that during the pipefish reproduction period in the Wadden Sea, $S$. muticum beds provide efficient feeding grounds for $E$. aequoreus.

Since the growth of Sargassum muticum in the Wadden Sea is pseudo-perennial, the algal biomass decreases drastically during late summer and early fall, when lateral branches detach (Jephson \& Gray 1977, Buschbaum et al. 2006). Therefore, S. muticum habitats are only temporarily available and do not support a resident fish fauna. While many pipefish species are considered to inhabit inshore habitats rather permanently (e.g. Kendrick \& Hyndes 2003, Oliveira et al. 2007), Entelurus aequoreus can be regularly found offshore. Whether the pelagic mode represents a certain stage in the life cycle of snake pipefish or whether the oceanic forms of E. aequoreus are even taxonomically different from the inshore form is unclear (see Kloppmann \& Ulleweit 2007 for details). Higher numbers of snake pipefish larvae in offshore plankton and of adult specimens in fish surveys might be a result of North Sea currents influencing the distribution of pipefish and their larvae, originating from inshore habitats. Active, seasonal inshore-offshore migrations are also possible, as has been documented for other syngnatid species, such as the northern pipefish Syngnathus fuscus, which leaves estuaries and moves offshore during winter (Lazzari \& Able 1990).

Kirby et al. (2006) and Lindley et al. (2006) attribute the sudden numerical increase of Entelurus aequoreus in the northeast Atlantic to a warming sea as a result of climate change, which is beneficial for reproduction and larval survival. Environmental factors such as changing temperatures or the overexploitation of food competitors probably affect stocks of pipefish. However, those factors might not explain the sudden increase in stock sizes. The present study does not provide an exclusive reason for the increase of snake pipefish in the northeast Atlantic, but, in our opinion, the introduction of Sargassum muticum is a key factor for the recovery of E. aequoreus in the Wadden Sea.
However, population dynamics and distribution patterns could not be demonstrated on a Wadden Sea scale in the present study, and we can only suggest that the settlement of pipefishes on transplanted S. muticum thalli occurred by passing pelagic specimens. However, since snake pipefish have been considered a red list species in the Wadden Sea (Berg et al. 1996), its sudden density and inshore aggregation in Sargassum habitats indicates a significant ecological function of S. muticum for these fish. Since $S$. muticum stocks are increasing in European waters (e.g. Critchley et al. 1987, Karlsson \& Loo 1999, Staehr et al. 2000), a subject of further research should be whether these stocks could potentially trigger the high abundances of snake pipefish currently found in the northeast Atlantic Ocean.

That the complex structure of Sargassum muticum provides a significant shelter from predation can only be assumed, since this was not investigated during the present study. However, in our experience, specimens of Entelurus aequoreus were difficult to spot within the algal canopy, since they mimic $S$. muticum branches in colour and form. That different pipefish species occupy certain macrophytes based on their ability to mimic morphology and colour was observed by Kendrick \& Hyndes (2003) in Western Australia. With their brownish colour and brighter markings, the camouflage of the snake pipefish we found matched $S$. muticum more closely than the seagrass (Zostera marina) habitats that they are documented to have formerly inhabited in the Wadden Sea area. Specimens recently illustrated or described (e.g. Froese \& Pauly 2007) show a colouration similar to fish found during the present study and therefore are well camouflaged within S. muticum. We were not able to determine whether $S$. muticum habitats promote $E$. aequoreus densities more than seagrass habitats by offering a substrate that provides better camouflage, or whether snake pipefish simply adapt their colour to a changing habitat as other syngnathids do. However, this information is considered important to evaluate whether the introduction of $S$. muticum to the Wadden Sea leads to a restoration of snake pipefish stocks or whether it rather leads to an overpopulation that might negatively affect ecosystem functioning. Since historical data on pipefish abundance before the decline of subtidal seagrass beds are not available, it is difficult to evaluate whether the present increase of pipefish stocks might exceed the carrying capacity of the ecosystem and negatively influence other biota via the food web. Examples of such negative influences have already been reported by Harris et al. (2007), who observed that E. aequoreus increasingly became part of the diet of seabirds in the northeast Atlantic, negatively affecting their breeding success because chicks could not swallow snake pipefish and a high number of juvenile birds choked. 
Beside snake pipefish, the sea stickleback Spinachis spinachia and the broad-nose pipefish Syngnathus typhle have been considered to be threatened in the Wadden Sea due to habitat loss (Berg et al. 1996). During the relatively short investigation period, 2 sea sticklebacks were observed within the transplanted Sargassum muticum thalli. Although the observation of 2 individuals is not enough to conclude that the alga affects the stock of S. spinachia in the Wadden Sea, it might indicate that a North Sea population of $S$. spinachia is still present in spite of the loss of Zostera marina habitats. In contrast to the snake pipefish and the sea stickleback, the broadnose pipefish Syngnathus typhle is probably still absent in the northern Wadden Sea since the disappearance of subtidal seagrass (Polte 2004). Since S. typhle occurs in relative proximity - about $300 \mathrm{~km}$ northward, in the Danish Limfjord - the species' geographical range does potentially allow a re-colonization of the Wadden Sea. Since reports of $S$. typhle to our knowledge are limited to seagrass habitats (e.g. Vincent et al. 1995, Riccato et al. 2003, Vizzini \& Mazzola 2004, Oliveira et al. 2007), this species might rely on seagrass habitats and not take advantage of alternative habitats provided by Sargassum spp.

The introduction of non-indigenous species to all varieties of ecosystems is considered to be a major threat to global biodiversity (e.g. Steneck \& Carlton 2001). However, depending on the capacity of ecological niches in the receptor system, it is also possible that introduced, habitat-forming organisms may promote the diversity of native communities instead of harming them. Buschbaum et al. (2006) found 60 species of epibionts associated with Sargassum muticum in the Wadden Sea, and a high number of them were originally rare in the area. However, there is also evidence of negative effects, e.g. on native algal assemblages caused by the introduction of $S$. muticum to other ecosystems. Britton-Simmons (2004), for example, showed that $S$. muticum introduced to the Pacific coast of the northern USA out-competed native macroalgae, and thus negatively affected the plant-grazer regime by limiting food availability to herbivores.

Thus, we conclude that the effects of non-indigenous, habitat-forming species such as Sargassum muticum may differ in distinct coastal systems. Although alteration of ecosystems by introduced species should never be promoted, consequences of introductions cannot be generalized but could be - and should beinvestigated in relationship to the unique characteristics of the receptor system.

Acknowledgements. Many thanks to Saskia Kroeckel, Annielyn Deocampo and the AWI diving team for all their assistance with field work and sample processing. We gratefully acknowledge Helen Berry, Tony Chapman, Bettina
Saier, Gerhard Cadée, Mike Harris, Karsten Reise and 3 anonymous referees for their valuable comments and their help to improve the manuscript. Thanks are extended to AWI for funding this research. The project was carried out within the framework of the MarBEF Network of Excellence 'Marine Biodiversity and Ecosystem Functioning' which is funded by the Sustainable Development, Global Change and Ecosystems Programme of the European Community's Sixth Framework Programme (Contract No. GOCE-CT-2003-505446). This publication is Contribution Number MPS-08012 of MarBEF.

\section{LITERATURE CITED}

Berg S, Krog C, Muus B, Nielsen J and others (1996) Red list of lampreys and marine fishes of the Wadden Sea. Helgol Meersunters 50:101-105

Britton-Simmons KH (2004) Direct and indirect effects of the introduced alga Sargassum muticum on benthic, subtidal communities of Washington State, USA. Mar Ecol Prog Ser 277:61-78

Buschbaum C (2005) Pest oder Bereicherung? Der eingeschleppte japanische Beerentang Sargassum muticum an der deutschen Nordseeküste. Natur Mus 135:216-221

Buschbaum C, Chapman AS, Saier B (2006) How an introduced seaweed can affect epibiota diversity in different coastal systems. Mar Biol 148:743-754

Critchley AT (1983) Sargassum muticum: a taxonomic history including world-wide and western Pacific distributions. J Mar Biol Assoc UK 63:617-625

Critchley AT, Nienhuis PH, Verschuure K (1987) Presence and development of populations of the introduced brown alga Sargassum muticum in the southwest Netherlands. Hydrobiologia 151/152:245-255

de Jonge VN, de Jong DJ, van Katwijk MM (2000) Policy plan and management measurements to restore eelgrass (Zostera marina L.) in the Dutch Wadden Sea. Helgol Mar Res 54:151-158

den Hartog C (1987) 'Wasting disease' and other dynamic phenomena in Zostera beds. Aquat Bot 27:3-14

Diederich S (2006) High survival and growth rates of introduced Pacific oysters may cause restrictions on habitat use by native mussels in the Wadden Sea. J Exp Mar Biol Ecol 328:211-227

Druehl L (1973) Marine transplantations. Science 179:12

Fletcher RL (1975) Studies on the recently introduced brown alga Sargassum muticum (Yendo) Fensholt. I. Ecology and reproduction. Bot Mar 28:149-156

Franco A, Franzoi P, Malavasi S, Riccato F, Torricelli P (2006) Fish assemblages in different shallow water habitats of the Venice Lagoon. Hydrobiologia 555:159-174

Froese R, Pauly D (2007) Fish Base. World Wide Web electronic publication 2007. Available at www.fishbase.org

Gätje C, Reise K (1998) Ökosystem Wattenmeer, Austausch-, Transport- und Stoffumwandlungsprozesse. Springer, Berlin

Harris MP, Beare D, Toresen R, Nøttestad L and others (2007) A major increase in snake pipefish (Entelurus aequoreus) in northern European seas since 2003: potential implications for seabird breeding success. Mar Biol 151:973-983

Harris MP, Newell M, Daunt F, Speakman JR, Wanless S (2008) Snake pipefish Entelurus aequoreus are poor food for seabirds. Ibis 150(2):413-415

Jackson EL, Rowden AA, Attrill MJ, Bossey SJ, Jones MB (2001) The importance of seagrass beds for fishery species. Oceanogr Mar Biol Annu Rev 39:269-303

Jephson NA, Gray PWG (1977) Aspects of the ecology of Sar- 
gassum muticum (Yendo) Fensholt, in the Solent Region of the British Isles. I. The growth cycle and epiphytes. In: Keegan BF, Ceidigh PO, Boaden PJS (eds) Biology of benthic organisms. Proc 11th Eur Symp Mar Biol, Galway 1976. Pergamon Press, Oxford, p 367-375

Karlsson J, Loo LO (1999) On the distribution and the continuous expansion of the Japanese seeweed Sargassum muticum in Sweden. Bot Mar 42:285-294

Kendrick AJ, Hyndes GA (2003) Patterns in the abundance and size-distribution of syngnathid fishes among habitats in a seagrass-dominated marine environment. Estuar Coast Shelf Sci 57:631-640

Kendrick AJ, Hyndes GA (2005) Variations in the dietary compositions of morphologically diverse syngnathid fishes. Environ Biol Fishes 72:415-427

Kirby RR, Johns DG, Lindley JA (2006) Fathers in hot waters: rising sea temperatures and a northeastern Atlantic pipefish baby boom. Biol Lett 2:597-600

Kloppmann MHF, Ulleweit J (2007) Off-shelf distribution of pelagic snake pipefish, Entelurus aequoreus (Linnaeus, 1758), west of the British Isles. Mar Biol 151:271-275

Kornmann P, Sahling PH (1994) Meeresalgen von Helgoland: zweite Ergänzung. Helgol Meersunters 48:365-406

Lazzari K, Able KW (1990) Northern pipefish, Syngnathus fuscus, occurrences over the Mid-Atlantic Bight continental shelf: evidence of seasonal migration. Environ Biol Fishes 27:177-185

Lindley JA, Kirby RR, Johns DG, Reid PC (2006) Exceptional abundance of the snake pipefish (Entelurus aequoreus) in the north-eastern Atlantic Ocean. ICES CM 2006/C:06

Nijssen H, de Groot SJ (1987) De Visschen van Nederland. K Ned Natuurhist Ver, Utrecht

Norton TA (1976) Why is Sargassum so invasive? Br Phycol J 11:197-198

Norton TA (1977) The growth and development of Sargassum muticum (Yendo) Fensholt. J Exp Mar Biol Ecol 26:41-53

Oliveira F, Erzini K, Gonçalves JMS (2007) Feeding habits of the deep-snouted pipefish Syngnathus typhle in a temperate coastal lagoon. Estuar Coast Shelf Sci 72:337-347

Pollard DA (1984) A review of ecological studies on seagrassfish communities, with particular reference to recent studies in Australia. Aquat Bot 18:3-42

Editorial responsibility: Erik Bonsdorf, Åbo, Finland and Karsten Reise, Sylt, Germany
Polte P (2004) Ecological functions of intertidal seagrass beds for fishes and mobile epibenthos in the northern Wadden Sea. PhD thesis, University of Bremen

> Polte P, Asmus H (2006) Influence of seagrass beds (Zostera noltii) on the species composition of juvenile fishes temporarily visiting the intertidal zone of the Wadden Sea. J Sea Res 55:244-255

Redeke HC (1941) Pisces (Cyclostomi-Euichthyes). Fauna van Nederland, Vol 10. Sijthof, Leiden

Riccato F, Fiorin R, Franco A, Franzoi P, Libertini A, Pranovi F, Torricelli P (2003) Population structure and reproduction of three pipefish species (Pisces, Syngnathidae) in a sea grass meadow of the Venice Lagoon. Biol Mar Mediterr 10:138-145

Rueness J (1989) Sargassum muticum and other introduced Japanese macroalgae: biological pollution of European coasts. Mar Pollut Bull 20:173-176

Staehr PA, Pedersen MF, Thomsen MS, Wernberg T, KrauseJensen D (2000) Invasion of Sargassum muticum in Limfjorden (Denmark) and its possible impact on the indigenous macroalgal community. Mar Ecol Prog Ser 207:79-88

Steneck RS, Carlton JT (2001) Human alterations of marine communities. Students beware! In: Bertness MD, Gaines SD, Hay ME (eds) Marine community ecology. Sinauer, Sunderland, MA, p 445-468

Tipton K, Bell SS (1988) Foraging patterns of two syngnathid fishes: importance of harpacticoid copepods. Mar Ecol Prog Ser 47:31-43

> Vincent ACJ, Berglund A, Ahnesjo I (1995) Reproductive ecology of five pipefish species in one eelgrass meadow. Environ Biol Fishes 44:347-361

Vizzini S, Mazzola A (2004) The trophic structure of the pipefish community (Pisces, Syngnathidae) from a western Mediterranean seagrass meadow based on stable isotope analysis. Estuaries 27:325-333

Wohlenberg E (1935) Beobachtungen über das Seegras Zostera marina L. und seine Erkrankung im nordfriesischen Wattenmeer. Nordelbingen 11:1-19

- Wolff WJ (2000) The south-eastern North Sea: losses of vertebrate fauna during the past 2000 years. Conserv Biol 95: 209-217

Wolff WJ (2005) Non-indigenous marine and estuarine species in The Netherlands. Zool Meded 79(1):1-116

Submitted: November 14, 2007; Accepted: April 4, 2008

Proofs received from author(s): June 18, 2008 